DOI: https://doi.org/10.35961/jppmkepri.v1i1.180

\title{
Meningkatkan Pemahaman Guru Melalui Pelatihan Online Pembuatan APE pada Kondisi Covid-19 di RA Al Falah Tanjungpinang
}

\author{
Ramli Muasmara $^{1 *}$, Mhd. Abror ${ }^{2}$, Syukri Ernayati Nurintan Sahri Sinaga ${ }^{3}$, Nadya Nela Rosa ${ }^{4}$, \\ Mukarramah $^{5}$ \\ 1,2, 3,4,5 STAIN Sultan Abdurrahman Kepulauan Riau, Bintan, Kepulauan Riau, 29123, Indonesia \\ *ramli_musmara@stainkepri.ac.id
}

\begin{abstract}
Abstrak
Anak usia dini dapat dioptimalkan tumbuh kembangnya dengan baik dengan upaya memberikan pendidikan, salah satunya melalui Raudhatul Athfal. Akan tetapi semenjak merebaknya wabah Covid-19, pemerintah mengambil kebijakan memberlakukan social distancing guna pencegahan virus. Instansi pendidikan kemudian mengalihkan pertemuan di kelas dengan pertemuan daring (online). Guru sangat menyadari bahwa dengan adanya kondisi ini pembelajaran dan materi yang disampaikan melalui grup WA orangtua siswa masih belum maksimal, ditambah lagi dengan media pembelajaran yang sulit untuk didapatkan. Padahal, ada beragam media alternatif yang dapat digunakan guru pada masa covid-19 seperti ini, diantaranya dengan membuat APE (Alat Pemainan Edukatif). Alat Permainan Edukatif adalah alat yang sengaja dibuat dengan bahan sederhana untuk keperluan pendidikan, bisa dari bahan bekas, alam dan sebagainya. Sebagai seorang guru, mengetahui berbagai media alternatif pembelajaran merupakan suatu tuntutan yang harus dikuasai guru. Adanya pelatihan online pembuatan APE pada kondisi covid-19 saat ini menjadi satu langkah inisatif dalam upaya meningkatkan pemahaman guru terhadap media pembelajaran anak usia dini yang memiliki nilainilai keislaman. Selama melakukan kegiatan, metode yang digunakan adalah ABCD. Berdasarkan hasil Pretest dan Post Test dari kegiatan tersebut, diketahui bahwa pemahaman guru terhadap APE semakin meningkat. Kemudian melalui pelatihan online ini guru tidak hanya memiliki wawasan tentang APE namun juga bisa menerapkannya kepada para peserta didik nantinya.
\end{abstract}

Kata kunci: Pemahaman, Pelatihan Online, APE, Covid-19

\begin{abstract}
Early childhood growth and development can be optimized by providing education, one of which is through Raudhatul Athfal. However, since the covid-19 pandemic, the government has taken a policy of imposing social distancing to prevent the virus. The educational institution then redirects the class meeting to online meetings. The teacher realizes that with this condition the learning and material delivered through the parents' Whatsapp group is still not optimal, coupled with learning media that are difficult to obtain. In fact, there are a variety of alternative media that teachers can use during Covid-19, including making educational games
\end{abstract}


(APE). Educational Game Tools are tools made with simple materials for educational purposes, it can be from used materials, nature and so on. As a teacher, knowing various alternative learning media is an important thing to learn. through online training on making APE in covid-19 conditions has become an initiative step in an effort to increase teachers' understanding of early childhood learning media that have Islamic values. During the activity, the method used is $A B C D$. Based on the results of the Pretest and Post Test from these activities, it is known that teachers' understanding of APE is increasing.

Keywords: Teacher's Understanding, Online Training, Educational Game Tools, Covid-19

\section{Pendahuluan}

Dunia pendidikan tingkat kanak-kanak adalah sebuah dunia yang tidak terlepas dari bermain dan juga berbagai alat permainan anak-anak. Salah satu lembaga pendidikan yang berperan penting dalam proses pembelajaran dan peningkatan mutu dunia pendidikan kanak-kanak adalah RA (Raudhah Athfal). Sebagai sebuah taman tentu saja RA merupakan sebuah tempat belajar dan juga bermain kanak-kanak yang memiliki berbagai sarana dan prasarana untuk mendukung terlaksanannya proses pembelajaran dengan baik dan berkualitas. Secara umum kegiatan belajar mengajar dilakukan di dalam ruang kelas. Akan tetapi pada masa pandemi seperti ini, pemerintah Indonesia telah memberlakukan penjajaran sosial (social distancing) dan melakukan lockdown pada semua daerah di Indonesia untuk mengurangi penyebaran virus Covid-19. Menteri Pendidikan dan Kebudayaan (Mendikbud) Nadiem Makarim bahkan telah mewajibkan agar lembaga pendidikan memberlakukan pembelajaran secara online sesuai surat Edaran Nomor 36962/MPK.A/HK/2020 tentang Pembelajaran secara daring (online) dan bekerja dari rumah dalam Rangka Pencegahan Penyebaran Covid-19. Kebijakan ini kemudian menjadi fenomena baru untuk dilaksanakan di seluruh daerah di Indonesia. Semua lembaga pendidikan baik TK hingga Universitas sudah mulai menerapkan kegiatan belajar online dan bekerja dari rumah sebagaimana yang juga telah dilakukan oleh RA Al-Falah Tanjungpinang.

Media daring (online) selama pandemi menjadi solusi yang harus dilakukan para guru dalam memaksimalkan media pembelajaran menggunakan E-Learning yaitu pembelajaran yang memanfaatkan teknologi informasi dan komunikasi. Sistem pembelajaran dilaksanakan menggunakan grup di media sosial seperti Whatsapp, telegram, aplikasi zoom ataupun media sosial lainnya yang dapat digunakan sebagai sarana pembelajaran sehingga dapat dipastikan siswa mengikuti pembelajaran diwaktu bersamaan meskipun ditempat yang berbeda. Guru harus berinovasi dalam mengeksplorasi cara belajar siswa agar siswa menjadi kreatif dengan memastikan pembelajaran tetap berjalan dan siswa mendapatkan ilmu sesuai kurikulum yang telah disusun.

Berdasarkan wawancara awal dilapangan, mayoritas guru mengeluhkan beberapa keterbatasan keadaan seperti adanya social distancing, kondisi perekonomian orangtua yang semakin menurun karena terdampak wabah covid 19, adanya masalah jaringan internet yang tidak merata dan cenderung kurang baik, memiliki anak usia sekolah lebih dari satu dan berbeda tingkatan sekolahnya, serta ketidaksiapan orangtua dalam memandu anak untuk belajar dirumah. Guru dalam hal ini menyadari bahwa dengan kondisi wabah covid-19, pembelajaran dan materi yang disampaikan melalui grup Whattsup orangtua siswa belum sepenuhnya berjalan maksimal bahkan ada siswa yang merasa jenuh dengan model pembelajaran yang diterapkan saat ini.

Selain itu pengetahuan guru tentang alternatif media belajar yang dapat digunakan oleh siswa di rumah masih sangat terbatas. Misalnya pengetahuan tentang APE (Alat Pemainan Edukatif) secara umum, 
maupun APE yang dibuat dari bahan bekas seperti kardus, botol, stik es krim dan lain-lain. Bahkan sebagian guru belum paham sepenuhnya arti, tujuan dan kegunaan APE (Alat Pemainan Edukatif), para guru hanya mengetahui APE sebatas sebagai pengguna mainan saja tanpa tahu secara lebih menyeluruh dan mendalam. Ditambah lagi guru-guru juga belum pernah mengikuti pelatihan pembuatan APE (Alat Pemainan Edukatif) dari barang bekas. Sepengetahuan mereka setiap APE (Alat Pemainan Edukatif) yang digunakan harus dibeli dengan harga yang cukup mahal.

Video penunjang untuk media pembelajaran alat permainan edukatif yang berbasis keislaman juga belum tersedia mengingat RA (Raudhatul Athfal) adalah lembaga yang memberikan pendidikan yang tidak hanya memperhatikan aspek jasmaniah saja tetapi juga aspek rohaniahnya yaitu dalam hal menanamkan nilai-nilai keimanan, keislaman, ibadah dan akhlak pada anak usia dini. RA Al-Falah memiliki kurikulum yang mengacu pada Permendiknas (Peraturan Pendidikan Nasional) nomor 58 tahun 2009 yaitu standar pendidikan anak usia dini yang menyeluruh dan mengintegrasikan aspek penanaman nilai-nilai agama dan moral, fisik, kognitif, bahasa, dan sosial-emosional.

Sepanjang penelusuran pengabdi, kajian pengabdian terhadap pelatihan pembuatan alat permainan edukatif masih relatif sedikit bahkan pelatihan online pembuatan APE (Alat Pemainan Edukatif) berwawasan keislaman bagi Guru RA (Raudhatul Athfal) secara khusus juga belum pernah dilakukan. Meskipun demikian, terdapat beberapa kajian terkait alat permainan edukatif baik dalam bentuk karya ilmiah maupun hasil kegiatan. Beberapa literatur dalam bentuk buku dan artikel adalah sebagai berikut:

1. Pengembangan Alat Permainan Edukatif Anak Usia Dini. Buku ini berisi ajakan untuk membuat dan mengembangkan alat permainan secara mandiri. Buku ini secara tidak langsung telah menumbuhkan semacam kesadaran reflektif bahwa APE (Alat Pemainan Edukatif) itu murah dan mudah. Apalagi bahanbahan dasar pembuatan APE (Alat Pemainan Edukatif) berada di sekitar lingkungan masyarakat. Sehingga para orangtua maupun guru bisa memanfaatkan barang-barang tersebut dalam pembuatan alat permainan sederhana (Dharmawijaya, 2016)

2. Panduan Praktikum Pemanfaatan APE (Alat Pemainan Edukatif) Tradisional untuk Menstimulasi Kecerdasan Anak. Buku Panduan ini merupakan modul praktikum penerapan APE (Alat Pemainan Edukatif) tradisional untuk anak usia dini yang dilakukan oleh mahasiswa sebagai kegiatan praktikum dengan tujuan untuk membantu mahasiswa dalam meningkatkan keterampilan prakteknya guna pemenuhan kebutuhan dalam penerapan pembelajaran (Dharmawijaya, 2016).

3. Upaya meningkatkan kreativitas anak melalui APE (Alat Pemainan Edukatif) pada kelompok B di RA Taqiyya Mangkubumen, Sukoharjo. Skripsi ini menjelaskan bahwa dengan alat permainan edukatif yang dimanfaatkan dari botol plastik bekas dapat meningkatkan kretivitas dan memunculkan ide kreatif anak (Tutik, 2012).

4. Pengaruh APE (Alat Pemainan Edukatif) bahan alam terhadap perkembangan kretivitas anak usia dini. Skripsi ini menjelaskan tentang pemanfaatan APE (Alat Pemainan Edukatif) berbahan alam berupa dedaunan dan pelepah pisang yang terbukti memiliki pengaruh dalam mengembangkan kreativitas anak usia dini (Ismiyunitasari, 2017).

5. Implementasi APE (Alat Pemainan Edukatif) dalam meningkatkan kreativitas anak Kelompok B usia 5-6 tahun di RA Nurul Amal Kec. Tanjung Morawa tahun ajaran 2018/2019. Skripsi ini menjelaskan tentang penerapan APE (Alat Pemainan Edukatif) dalam meningkatkan kreativitas anak yang secara langsung dibimbing oleh guru RA Nurul Amal (Pane, 2018)

Berdasarkan kajian terdahulu dapat diketahui bahwa judul yang telah dilakukan oleh penulis sebelumnya hanya berkisar pada pembuatan APE (Alat Pemainan Edukatif) secara sederhana dan berbasis pada wawasan kebangsaan. Namun hal ini berbeda dengan judul pengabdian yang akan dilaksanakan oleh dosen pengabdi yang mana judulnya telah disesuaikan dengan kondisi pandemi covid-19 saat ini. Oleh karena itu pengabdian mengenai pelatihan online pembuatan APE (Alat Pemainan Edukatif) bagi Guru pada 
kondisi Covid-19 di RA Alfalah Kota Tanjungpinang merupakan judul baru dan belum pernah dilaksanakan oleh dosen pengabdi lainnya khususnya untuk wilayah Tanjungpinang.

Alat permainan edukatif merupakan bagian yang tidak terpisahkan dalam pembelajaran anak di TK. Ketersediaan alat permainan tersebut sangat menunjang terselenggaranya pembelajaran anak secara efektif dan menyenangkan sehingga anak-anak dapat mengembangkan berbagai potensi yang dimilikinya secara optimal. Secara umum banyak para penyelenggara pendidikan TK/RA dan guru TK/RA yang berpendapat bahwa memperoleh Alat Permainan Edukatif dengan cara membeli adalah lebih mudah dan ekonomis.

Namun jika para guru mau berkreasi dan berinovasi untuk menciptakan Alat Permainan Edukatif dari barang-barang bekas maka tentu saja akan lebih ekonomis lagi. Oleh karena itu, melalui kegiatan pelatihan pembuatan APE (Alat Pemainan Edukatif) secara online bagi guru RA (Raudhatul Athfal) ini diharapkan guru dapat menggali kemampuannya dalam menciptakan dan memanfaatkan barang-barang disekitar lingkungan sekolah menjadi alat permainan edukatif yang bermanfaat bagi murid-murid di sekolah.

Alat permainan edukatif yang baik diharapkan mampu menjadi sarana yang dapat mendorong anak bermain bersama, mengembangkan daya fantasi, multi fungsi, menarik, berukuran besar dan awet, tidak membahayakan, disesuaikan dengan kebutuhan, desain mudah dan sederhana, serta bahan-bahan yang digunakan murah dan mudah diperoleh (Zaman dan Hernawan, 2014). Selain itu, pembuatan APE (Alat Pemainan Edukatif) yang baik juga mampu mengembangkan totalitas kepribadian anak, bukan karena kebagusan bentuknya, tetapi karena aspek kreatifitasnya, sehingga mampu menjadi sarana bermain yang aktif, menarik, menyenangkan dan bermanfaat.

Namun jika para guru mau berkreasi dan berinovasi untuk menciptakan Alat Permainan Edukatif dari barang-barang bekas maka tentu saja akan lebih ekonomis lagi. Oleh karena itu, melalui kegiatan pelatihan pembuatan APE (Alat Pemainan Edukatif) secara online bagi guru RA (Raudhatul Athfal) ini diharapkan guru dapat menggali kemampuannya dalam menciptakan dan memanfaatkan barang-barang disekitar lingkungan sekolah menjadi alat permainan edukatif yang bermanfaat bagi murid-murid di sekolah.

Alat permainan edukatif yang baik diharapkan mampu menjadi sarana yang dapat mendorong anak bermain bersama, mengembangkan daya fantasi, multi fungsi, menarik, berukuran besar dan awet, tidak membahayakan, disesuaikan dengan kebutuhan, desain mudah dan sederhana, serta bahan-bahan yang digunakan murah dan mudah diperoleh (Zaman dan Hernawan, 2014). Selain itu, pembuatan APE (Alat Pemainan Edukatif) yang baik juga mampu mengembangkan totalitas kepribadian anak, bukan karena kebagusan bentuknya, tetapi karena aspek kreatifitasnya, sehingga mampu menjadi sarana bermain yang aktif, menarik, menyenangkan dan bermanfaat.

\section{Metode}

Untuk mendapatkan hasil terbaik dalam pelaksanaan pengabdian kepada masyarakat, maka diperlukan suatu metode yang relevan. Dalam pelaksanaan pengabdian kepada masyarakat ini, tim menggunakan metode ABCD (Asset Based Community-Driven Development). Metode ABCD (Asset Based Community-Driven Development) berupaya memberdayakan masyarakat dengan mengenali aset-aset yang dimilikinya, baik yang bersifat materi maupun imateri, sebagai modal awal untuk mengembangkan masyarakat tersebut (Dureu, 2013).

Dalam pengabdian masyarakat ini, kegiatan inti yang dilakukan oleh tim adalah "Pelatihan Online Pembuatan APE (Alat Pemainan Edukatif) bagi Guru pada Kondisi Covid-19 di RA. Al-Falah Kota Tanjungpinang ", dengan menggunakan metode ABCD (Asset Based Community-Driven Development) ini, Tim menggali potensi ataupun aset yang dimiliki oleh Guru-guru RA Al-Falah yang ada di Kota Tanjungpinang, baik berupa materi maupun immateri. Aset yang berupa materi seperti bahan-bahan bekas di 
lingkungan sekolah / rumah yang dijadikan dan dikembangkan sebagai APE (Alat Permainan Edukatif) yang memiliki wawasan nilai-nilai keislaman, sehingga APE (Alat Permainan Edukatif) ini tidak hanya sebagai alat untuk permainan anak-anak tapi memiliki nilai-nilai keislaman yang akan menumbuhkan keimanan bagi peserta didik.

Dari hasil observasi awal oleh tim pengabdian kepada masyarakat, maka didapatilah beberapa masalah berikut ini :

1) Pengetahuan guru tentang APE (Alat Pemainan Edukatif) secara umum, maupun APE (Alat Permainan Edukatif) yang dibuat dari bahan bekas seperti kardus, botol, tutup botol, stik eskrim dll masih kurang;

2) Bahkan sebagian guru belum paham sepenuhnya tentang APE (Alat Pemainan Edukatif), sebelumnya para guru hanya sebatas sebagai pengguna mainan itu saja tanpa lebih tau secara menyeluruh dan lebih mendalam;

3) Guru-guru belum pernah mengikuti pelatihan tentang APE (Alat Permainan Edukatif) ataupun pelatihan pembuatan APE (Alat Permainan Edukatif) dari barang bekas. Sepengetahuan mereka setiap APE (Alat Permainan Edukatif) yang digunakan harus dibeli dengan harga yang cukup mahal.

Dengan adanya beberapa fakta di atas, maka dipandang pentinglah diadakannya pelatihan ini. Kemudian, model atau pendekatan yang digunakan oleh tim pengabdian kepada masyarakat dalam kegiatan ini adalah pendekatan kuantitatif, dimana dalam pengumpulan data, tim menggunakan abservasi dan survei online berupa Pre Test kepada guru RA. Al-Falah Tanjungpinang, untuk mengetahui tingkat pemahaman mereka tentang APE (Alat Permainan Edukatif). Kemudian, dilaksanakan pelatihan Online tentang Pembuatan APE (Alat Permainan Edukatif) serta dilakukan Post Test untuk mengukur bagaimana peningkatan pengetahuan guru tentang APE (Alat Permainan Edukatif) tersebut. Peserta yang mengikuti pelatihan tersebut adalah majelis guru yang ada di RA. Al-Falah Kota Tanjungpinang dengan jumlah keseluruhan 24 orang.

Dalam pelaksanaan kegiatan pelatihan online ini, ada beberapa kendala yang dialami oleh tim :

1) Jaringan: untuk melaksanakan pelatihan online diperlukan jaringan dan koneksi yang baik dan kuat, pada kenyataannya beberapa guru tidak bisa mengikuti pelatihan online langsung via Zoom disebabkan berada di daerah yang minim jaringannya;

2) Kurangnya pengetahuan tentang teknologi: beberapa guru juga tidak bisa ikut pelatihan online langsung via Zoom disebabkan karena kurangnya pengatahuan tentang teknologi walaupun tim sudah melakukan pembimbingan.

Maka, untuk pengatasi kendala tersebut, tim juga melaksanakan pelatihan melalui media sosial yaitu WA group, yang dipandang tidak terlalu memerlukan jaringan yang kuat dan manyoritas guru bisa menggunakannya. Kemudian, hasil yang diinginkan dengan adanya pelatihan Pembuatan APE (Alat Pemainan Edukatif) ini adalah sebagai berikut :

1) Meningkatnya pengetahuan guru RA. Al-Falah tentang APE (Alat Pemainan Edukatif);

2) Majelis guru bisa membuat sendiri APE (Alat Pemainan Edukatif) yang berasal dari barang-barang bekas yang ada di lingkungan sekolah atau rumah yang ramah dan murah;

3) Mejelis guru dapat mengembangkan pengetahuan tentang APE (Alat Pemainan Edukatif) yang memiliki nilai-nilai keislaman

Majelis guru bisa menggunakan APE (Alat Permainan Edukatif) tersebut dalam proses pembelajaran sambil bermain bagi peserta didik, khusunya pada kondisi Covid-19 yang mengharuskan proses belajar mengajar dari rumah. 


\section{Hasil dan Pembahasan}

Secara umum, guru merupakan elemen kunci dalam sistem pendidikan, khususnya di sekolah. Semua komponen lain mulai dari kurikulum, sarana dan prasarana, pembiayaan dan sebagainya tidak akan berarti apabila esensi pembelajaran yakni interaksi antara guru dengan peserta didik tidak berkualitas. Begitu pentingnya peranan guru dalam mentranformasikan input-input pendidikan, sampai-sampai banyak pakar menyatakan bahwa di sekolah tidak akan ada perubahan atau peningkatan kualitas tanpa adanya perubahan dan peningkatan kualitas guru.

Mengingat pentingnya peran guru di sekolah, maka sudah sewajarnyalah bila kompetensinya harus selalu ditingkatkan. Salah satu upaya yang dapat dilakukan dalam meningkatkan kompetensi guru adalah mmberikan pelatihan pembuatan alat permainan edukatif. Hal ini dilakukan dengan tujuan agar guru bisa membuat alat permainan edukatif secara mandiri sesuai dengan tema yang akan disampaikan kepada murid serta untuk memberikan motivasi dan merangsang murid untuk bereksplorasi dan bereksperimen dalam mengembangkan berbagai aspek perkembangannya dan tentunya dapat menunjang keberhasilan belajar murid di sekolah.

Selama kegiatan berlangsung, para guru diajarkan tentang materi APE (Alat Permainan Edukatif) mulai dari definisi, fungsi, tujuan, kegunaan, prinsip, karakteristik, syarat, jenis hingga ragam bentuk contoh APE (Alat Pemainan Edukatif) . Selain itu didukung pula dengan penjelasan pembuatan APE berwawasan keislaman dari barang bekas melalui video seperti busy book, panggung boneka dan puzzle hijaiyah. Hal ini dilakukan agar para guru bisa mengenal dan membuat APE (Alat Permainan Edukatif) yang bernilai keislaman.

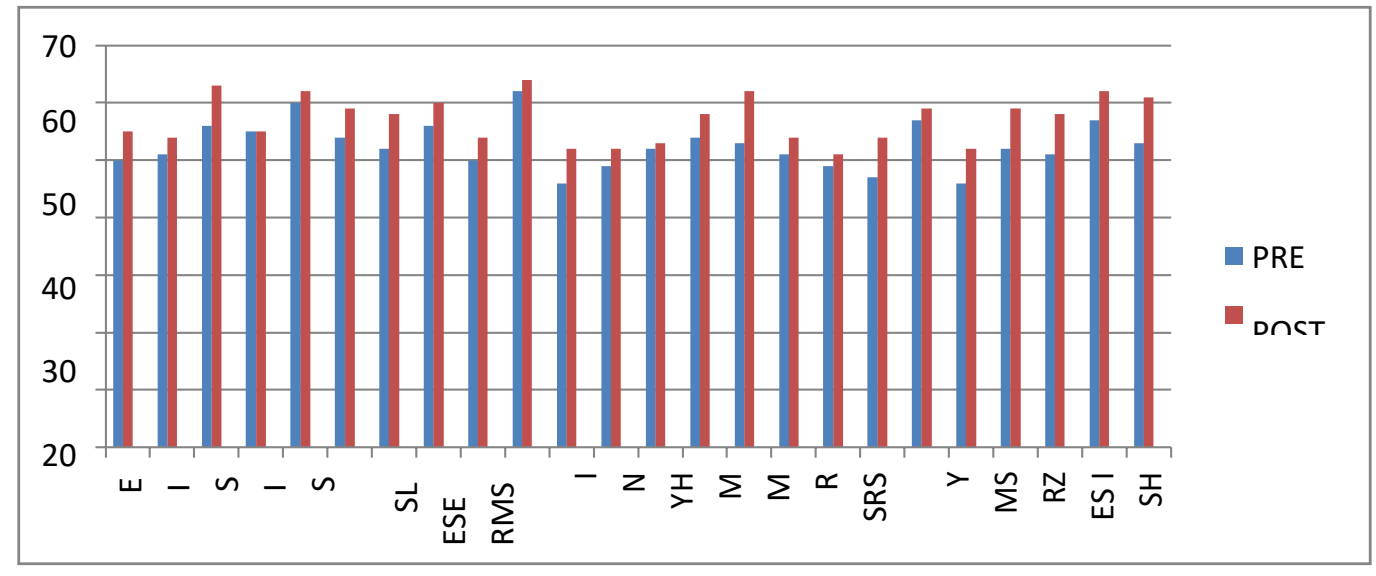

Gambar 1. Grafik Skor Pretest dan Post Test

Berdasarkan tabel grafik diatas dapat dilihat bahwa pelatihan yang dilaksanakan memiliki dampak meningkatkan pengetahuan para peserta terhadap pelatihan APE (Alat Permainan Edukatif). Dari pelatihan yang diberikan sebanyak 24 peserta mengalami peningkatan. Secara keseluruhan dapat dilihat bahwa pelatihan yang dilakukan bermanfaat untuk memberikan pengatahuan dan meningkatkan kemampuan peserta pelatihan terkait APE (Alat Permainan Edukatif) yang dapat dimanfaatkan sebagai media pembelajaran yang kreatif dan menarik bagi peserta didik.Untuk penelitian kualitatif, bagian hasil memuat bagian-bagian rinci dalam bentuk sub topik-sub topik yang berkaitan langsung dengan fokus penelitian dan kategori-kategori. 
Tabel 1

T-Test Paired Samples Statistics

\begin{tabular}{|c|c|c|c|c|c|}
\hline & & Mean & $\mathrm{N}$ & Std. Deviation & Std. Error Mean \\
\hline \multirow[t]{2}{*}{ Pair 1} & PRE & 52.6250 & 24 & 4.07338 & .83147 \\
\hline & POST & 57.1250 & 24 & 4.01424 & .81940 \\
\hline
\end{tabular}

Tabel 2

Paired Samples Test

\begin{tabular}{|c|c|c|c|c|c|c|c|c|}
\hline & \multicolumn{5}{|c|}{ Paired Differences } & \multirow[b]{3}{*}{$\mathrm{T}$} & \multirow[b]{3}{*}{ df } & \multirow{3}{*}{$\begin{array}{l}\text { Sig. (2- } \\
\text { tailed) }\end{array}$} \\
\hline & \multirow[b]{2}{*}{ Mean } & \multirow{2}{*}{$\begin{array}{c}\text { Std. } \\
\text { Deviatio } \\
\mathrm{n}\end{array}$} & \multirow{2}{*}{$\begin{array}{c}\text { Std. } \\
\text { Error } \\
\text { Mean }\end{array}$} & \multicolumn{2}{|c|}{$\begin{array}{l}95 \% \text { Confidence } \\
\text { Interval of the } \\
\text { Difference }\end{array}$} & & & \\
\hline & & & & Lower & Upper & & & \\
\hline $\begin{array}{ll}\text { Pair } & \text { PRE - } \\
1 & \text { POST }\end{array}$ & -4.50000 & 2.37743 & .48529 & -5.50390 & -3.49610 & -9.273 & 23 & .000 \\
\hline
\end{tabular}

Berdasarkan hasil pengukuran diatas diperoleh $0,000<0,05$, dapat disimpulkan bahwa terdapat perbedaan yang signifikan terhadap perubahan pengetahuan peserta pelatihan terhadap materi pelatihan APE (Alat Permainan Edukatif) setelah mengikuti pelatihan.

Tabel 3

\section{Jadwal Pelaksanaan Kegiatan}

\begin{tabular}{|c|c|c|c|c|}
\hline No & Waktu & Uraian Kegiatan & Tempat & Ket \\
\hline 1 & $5-8$ Mei 2020 & Pengumpulan data kegiatan & RA Al Falah (sesuai Protokol & TIM \\
belajar mengajar RA Al Falah & kesehatan) dan Daring & \\
\hline 2 & $8-15$ Mei 2020 & Pembuatan video Tutorial APE & Daring & TIM \\
\hline 3 & $16-20$ Mei 2020 & Tutorial penggunaan aplikasi & Grup WA & TIM \\
& & zoom dan pengisian pree test & & TIM \\
\hline 4 & 21 Mei 2020 & Pelatihan online pembuatan APE & Aplikasi zoom & \\
\hline
\end{tabular}




\begin{tabular}{|c|c|l|c|c|}
\hline 5 & $26-312020$ & Lanjutan Pelatihan online & Grup WA & TIM \\
& & $\begin{array}{l}\text { pembuatan APE (Share hasil } \\
\text { pelatihan) }\end{array}$ & & \\
\hline 6 & $1-8$ Juni 2020 & Penyusunan hasil pelatihan & Rumah & TIM \\
\hline 7 & $10-17$ Juni 2020 & Penyusunan Laporan Pengabdian & Rumah & TIM \\
\hline
\end{tabular}

\section{Kesimpulan}

Berdasarkan hasil pengabdian yang telah dilakukan, maka dapat dikemukakan beberapa kesimpulan antara lain sebagai berikut:

1. APE (Alat Pemainan Edukatif) merupakan alat permainan yang sengaja dibuat untuk anak TK guna kepentingan pendidikan.

2. Guru memiliki peran penting di sekolah, sehingga kemampuan guru terhadap media pembelajaran harus ditingkatkan.

3. Melalui pelatihan online pembuatan APE (Alat Pemainan Edukatif) para guru mendapatkan pemahaman tentang materi APE (Alat Pemainan Edukatif) berwawasan keislaman dari barang bekas seperti busy book, panggung boneka, dan puzzle hijaiyah

4. Setelah mengikuti pelatihan, scara umum dari 24 peserta semuanya mengalami peningkatan pengetahuan secara signifikan tentang APE (Alat Pemainan Edukatif)

\section{Saran}

Pada akhir penulisan jurnal ini, pengbdi ingin menyampaikan beberapa saran yang berkaitan dengan pelatihan online alat permainan edukatif bagi guru di masa Covid-19 antara lain sebagai berikut :

1. Saran untuk STAIN Sultan Abdurrahman Kepulauan Riau untuk lebih memperbanyak buku-buku pendidikan anak usia dini di perpustakaan.

2. Saran untuk RA Alfalah untuk lebih giat mempelajari media sosial yang berkembang saat ini seperti whattsapp, zoom dan sebagainya guna untuk pengembangan pendidikan yang lebih baik khususnya di masa pandemic Covid-19. Selain itu, diharapkan RA Alfalah dapat mendukung tenaga pendidik dalam membuat APE (Alat Pemainan Edukatif) yang bernilai keislaman agar murid-murid tidak hanya cerdas secara intelegensi namun juga secara emosional dan spiritual.

3. Saran untuk para guru untuk lebih mendalami pembuatan APE (Alat Pemainan Edukatif) karena APE merupakan media belajar yang dapat digunakan untuk keperluan pendidikan dan tentunya dapat dibuat dengan alat dan bahan yang sederhana.

4. Saran untuk para mahasiswa-mahasiswi PIAUD (Pendidikan Islam Anak Usia Dini) agar sebaiknya lebih memperhatikan dan mendalami kajian tentang APE (Alat Pemainan Edukatif) yang bernilai keislaman karena kajian tersebut sangat dekat dengan anak-anak usia dini.

\section{Ucapan Terimakasih}

Penulis mengucapkan terima kasih yang sebesar-besarnya kepada pihak yang telah memberi dukungan moral serta dana atas terselenggaranya program pengabdian masyarakat ini :

1. Ketua STAIN Sultan Abdurrahman Kepulauan Riau 
2. TIM Reviewer

3. P3M STAIN Sultan Abdurrahman Kepulauan Riau

4. Ketua Prodi PIAUD (Pendidikan Islam Anak Usia Dini) STAIN Sultan Abdurrahman Kepulauan Riau

5. Kepala Sekolah dan Guru RA Al Falah Kota Tanjungpinang.

\section{Referensi}

Dharmawijaya, H. (2016). Pemanfaatan alat permainan edukatif (ape) tradisional untuk menstimulasi

Dureau, C. (2013) Pembaru dan kekuatan lokal untuk pembangunan. Australia: Australian Community Development and Civil Society Strengthening Scheme (ACCESS) Phase II.

Ismiyunitasari. (2017). Pengaruh ape (alat pemainan edukatif) bahan alam terhadap perkembangan kretivitas anak usia dini. (Bachelor thesis, UIN Raden Intan, Indonesia). Retrieved from http://repository.radenintan.ac.id/2729/1/SKRIPSI_ISMI_FIX.pdf.

kecerdasan anak program studi pendidikan guru pendidikan anak usia dini. Indralaya: Universitas Sriwijaya Press.

Purnama, S. (2019). Pengembangan alat permainan edukatif anak usia dini. Bandung: Rosda Karya.

Pane, E. S. (2018). Implementasi ape (alat pemainan edukatif) dalam meningkatkan kreativitas anak kelompok b usia 5-6 tahun di ra nurul amal kec. tanjung morawa tahun ajaran 2018/2019 (Bachelor thesis, UIN Sumatera Utara, Indonesia). Retrieved from http://repository.uinsu.ac.id/6131/1/ Skripsi\%20Tanpa\%20TTD.pdf.

Tutik. (2012). Upaya meningkatkan kreativitas anak melalui alat permainan edukatif pada kelompok b di ra taqiyya Mangkubumen, Sukoharjo. (Bachelor thesis, Universitas Muhammadiyah Surakarta, Indonesia). Retrieved from http://eprints.ums.ac.id/19096/9/11._Naskah_Publikasi.pdf.

Zaman, B., Hernawan, H. (2009). Media dan sumber belajar paud. Jakarta: Universitas Terbuka. 